УДК 616.12-007-053.1-008.87-07

\title{
Мікробіологічний моніторинг розвитку бактеріємії у дітей із вродженими вадами серця
}

\author{
Філоненко Г.В. ${ }^{1}$, Саламаніна А. О. ${ }^{1}$, Кирик Д. Л. ${ }^{2}$ \\ ${ }^{1}$ ДУ «Науково-практичний медичний центр дитячої кардіології та кардіохірургії МОЗ України» (Київ) \\ ${ }^{2}$ Національна медична академія післядипломної освіти імені П. Л. Шупика (Київ)
}

\begin{abstract}
Результати аналізу стану проблеми післяопераційної бактеріальної інфекції дозволяють виділити аспекти, обговорення яких на сучасному етапі становить особливу актуальність та значущість для кардіохірургії високих технологій. Мета дослідження - визначити частоту розвитку бактеріємії та ії етіологічну структуру в дітей першого року життя із вродженими вадами серця (ВВС). Методи - мікробіологічні, статистичної обробки. Результати. Проведено порівняльний аналіз результатів бактеріологічного дослідження проб крові, отриманих від 218 дітей першого року життя, прооперованих у зв'язку із ВВС за період 2015-2016 pp. Встановлено, що у спектрі збудників бактеріємії у дітей за 2015 р. переважали неферментуючі мікроорганізми $(43,1 \%)$, а у пацієнтів за 2016 р. - коагулазонегативні стафілококи (25,6\%). Висновки. Дітей першого року життя з ВВС необхідно включити в групу ризику розвитку бактеріємій та інших післяопераційних інфекційних ускладнень (ІУ). Мікробіологічний моніторинг є однією з головних складових системи інфекційного контролю в кардіохірургічних стаціонарах, що забезпечує науково обгрунтовану антибіотикотерапію і профілактику ІУ. Подальші дослідження повинні бути спрямовані на визначення молекулярно-генетичних детермінант антибіотикорезистентності, в першу чергу до бета-лактамаз розширеного спектру дії та карбапенемаз.
\end{abstract}

Ключові слова: діти, бактеріємія, вроджені вади серия.

Результати аналізу стану проблеми післяопераційної бактеріальної інфекції дозволяють виділити аспекти, обговорення яких на сучасному етапі є особливо актуальним і значущим для кардіохірургії високих технологій. Згідно з літературними даними, післяопераційні інфекційні ускладнення (ІУ) в кардіохірургії проявляються в різних клінічних формах - від окремих епізодів і хронічних процесів до генералізованого процесу з переходом у сепсис [1,5].

Згідно зі статистичними даними, смертність серед кардіохірургічних пацієнтів з IУ в 2-4 рази вища, ніж серед пацієнтів із легким перебігом післяопераційного періоду [1-3]. У середньому питома вага ІУ в кардіохірургії коливається від 3 до 8\%, інфекцій місць хірургічних втручань (IMXB) - від 1,3 до 12,8\% [2, 4].

Головною причиною формування госпітальних штамів мікроорганізмів $\epsilon$ широке i не завжди раціональне застосування антибіотиків, а їх поширення і персистенція відбуваються внаслідок недостатньо ефективних заходів інфекційного контролю [5].

Мета дослідження - визначити частоту розвитку бактеріємії та іï етіологічну структуру у дітей першого року життя із вродженими вадами серця (ВВС).

Матеріали та методи. За період із січня 2015 р. по грудень 2016 р. було виконано 944 мікробіологічні дослідження у 218 дітей першого року життя із ВВС, яким проведено оперативне лікування в ДУ «НПМЦДКК
MO3 України». Середній вік пацієнтів становив $102,0 \pm 8,1$ дня (від 0 д. до 1 р.), середня вага $-4,5 \pm 2,1$ кг (від 1 кг до 12,1 кг). Розподіл за статтю був таким: 117 $(53,7 \%)$ пацієнтів - чоловічої статі, 101 (46,3\%) - жіночої. Середня тривалість перебування в стаціонарі - 34,4 $\pm 2,1$ ліжко/днів (від 1 до 316 л/д). Дослідження проводили в післяопераційному періоді при тривалій лихоманці, що перевищувала терміни, які відповідають критеріям системної запальної відповіді на штучний кровообіг, а також при наявності гіпертермії або перших симптомів ІУ. Більшість дітей з ускладненим перебігом післяопераційного періоду були прооперовані у зв'язку зі складними поєднаними пороками серця: транспозиція магістральних судин, коарктація аорти, спільний артеріальний стовбур, тотальний аномальний дренаж легеневих вен.

Для бактеріологічного дослідження крові використовували автоматичну систему BacT/ Alert $3 D$ (bioMerieux, Франція). Кров пацієнтів відбирали у спеціальні флакони, які містили поживне середовище для культивування аеробних та анаеробних мікроорганізмів. Ідентифікацію та визначення рівня стійкості мікроорганізмів до антибіотиків визначали на бактеріологічному аналізаторі VITEK 2 COMPACT (bioMerieux, Франція).

Статистична обробка даних проводилася за допомогою програм WHONET 5,6 та STATISTICA 6,0. 


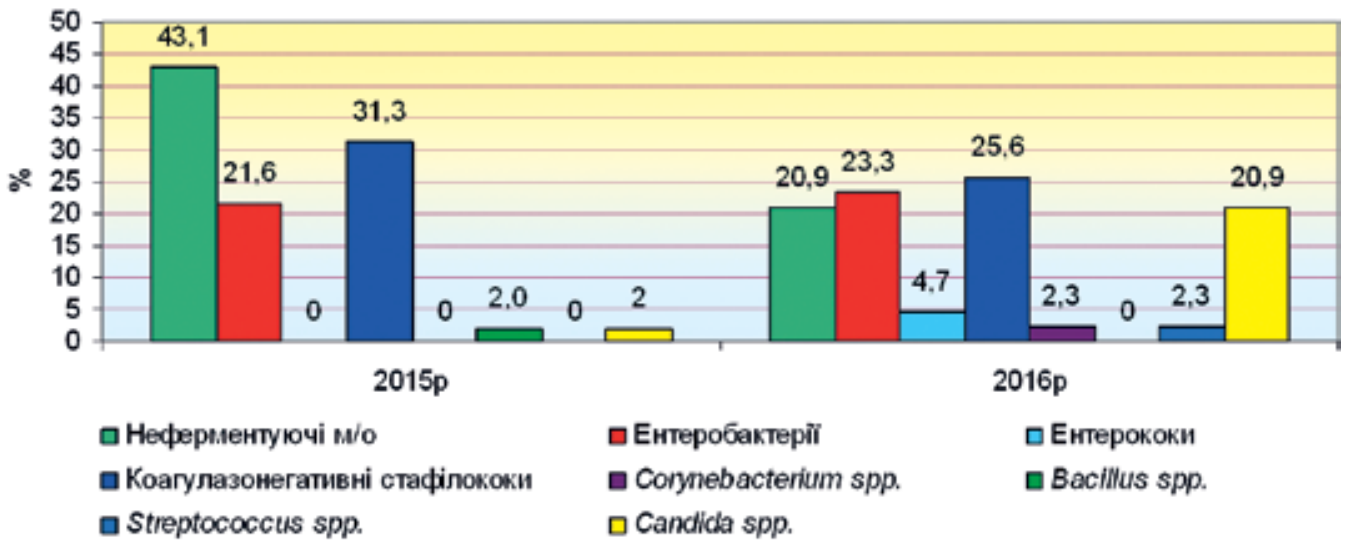

Рис. 1. Загальний спектр збудників бактеріємії за 2015-2016 рp.

Результати дослідження. Частота розвитку бактеріємії у дітей першого року життя з ВВС у 2015 р. була $29,5 \%(\mathrm{n}=51)$, а в 2016 p. $-21,1 \%(\mathrm{n}=44)$. Монокультури виділили у 56 хворих, мікробних асоціацій не було виявлено.

Етіологічна структура збудників бактеріємії представлена грамнегативними штамами бактерій (ГНБ) у $52(54,7 \%)$ випадках, у тому числі $21(22,1 \%)$ штам віднесено до ентеробактерій і $31(32,6 \%)$ - до неферментуючих мікроорганізмів (НФМ). Із зразків крові обстежених пацієнтів також виділяли грампозитивні бактерії (ГПБ) у $33(34,7 \%)$ випадках, у тому числі - 21 $(28,4 \%)$ каталазопозитивний і $3(3,1 \%)$ - каталазонегативні коки, а в $10(10,5 \%)$ випадках бактеріємія була зумовлена грибами роду Candida spp. (рис. 1).

Видовий склад ентеробактерій у 2015 р. був представлений в основному Serratia marcescens $(\mathrm{n}=7)$ та Klebsiella pneumonia $(\mathrm{n}=4)$, а в 2016 p. - Klebsiella pneumonia $(\mathrm{n}=7)$, Enterobacter cloacea $(\mathrm{n}=2)$ та Escherichia coli $(\mathrm{n}=1)$. 3pocла частота виділення ентеробактерій продуцентів бета-лактамаз розширеного спектру дії та карбапенемаз. Основна причина цього була пов'язана з переведенням з інших стаціонарів новонароджених, колонізованих полірезистентними штамами Klebsiella pneumonia.

У 2016 р. порівняно 32015 р. частота виділення НФМ зменшилася майже вдвічі (3 43,1\% у 2015 р. до 20,9\% у 2016 р.). Їх склад у 2015 році представлений двома видами - Acinetobacter baumannii $(35,3 \%)$ та Stenotrophomonas maltophilia (7,8\%), а в 2016 p. - Stenotrophomonas maltophilia (9,1\%), Pseudomonas aeruginosa (6,8\%), Sphingomonas paucimobilis та Acinetobacter baumannii по 2,3\% відповідно.

Серед ГПБ, виділених у дітей при бактеріємії за 2015 та 2016 pp., переважали збудники роду Staphylococcus spp. відповідно $31,4 \%$ та 25,0\%. Серед коагулазопозитивних стафілококів у 2015 р. переважав St. epidermidis (13,7\% ), St. hominis (9,8\%), St. haemolyticus (5,9\%), St. warneri (2,0\%), a y 2016 p. - St. epedermidis (9,8\%), St. haemolyticus та St. hominis по 6,8\% відповідно, St. saprophyticus (2,3\%). За період дослідження Staphylococcus aureus не було виявлено у дітей першого року народження.

За період спостереження в 10 разів (2,0\% у 2015 р. та 20,9\% у 2016 р.) збільшилася частота виділення грибів роду Candida. У 2015 р. гриби роду Candida представлені одним видом - Candida albicans $(2,0 \%)$, тоді як у 2016 р. збудниками бактеріємії є Candida albicans $(9,1 \%)$ і Candida parapsilosis $(11,4 \%)$. Сепсис з різним поєднанням вогнищ запалення зареєстрований у 6 пацієнтів, що склало $2,7 \%$.

Установлено також, що позитивна гемокультура може бути результатом випадкової контамінації або відображати короткочасний стан транзиторної циркуляції бактерій під впливом різноманітних несприятливих факторів [6]. У нашому дослідженні в одному випадку виявлено Bacillus spp. у 2015 р. та Corynebacterium amycolatum y 2016 p., що було результатом контамінації зразка при заборі крові із катетера.

В останні роки відзначається тривожна тенденція збільшення частоти випадків розвитку інфекцій, пов'язаних із полірезистентними неферментуючими збудниками, які характеризуються непередбачуваним профілем антибіотикорезистентності, що зумовлює значне підвищення ризику призначення неадекватної схеми лікування.

\section{Висновки}

- Дітей першого року життя з ВВС необхідно включити у групу ризику розвитку бактеріємій та інших післяопераційних ІУ.

- Мікробіологічний моніторинг є однією з провідних складових системи інфекційного контролю в кардіохірургічних стаціонарах, що забезпечує науково обгрунтовану антибіотикотерапію та профілактику ІУ.

- Подальші дослідження повинні бути спрямовані на визначення молекулярно-генетичних детермінант антибіотикорезистентності, в першу чергу до беталактамаз розширеного спектру дії та карбапенемаз. 


\section{Література}

1. Epidemiology of community-acquired bacteremia among infants in a medical center in Taiwan, 2002-2011 / Y.-T. Ting [et al.] // Journal of Microbiology, Immunology and Infection. - 2015. - Vol. 48 (4). - P. 413-8.

2. Community-acquired neonatal and infant sepsis in developing countries: efficacy of WHO's currently recommended antibiotics-systematic review and metaanalysis / L. Downie [et al.] // Arch Dis Child. - 2013. Vol. 98 (1). - P. 146-54.

3. Distinguishing true coagulase-negative Staphylococcus infections from contaminants in the neonatal intensive care unit / C. M. Healy [et al.] // J Perinatol. - 2013. - Vol. 33 (1). - P. 52-8.

4. Changing epidemiology of bacteremia in infants aged 1 week to 3 months / T. L. Greenhaw [et al.] // Pediatrics. 2012. - Vol. 129 (3). - P. 590-6.

5. Kyryk D. L. Microbiologocal monitoring and analysis of bacteriemia in children with congenital heart diseases / D. L. Kyryk., H. V. Filonenko // Collection of scientific works of staff members of NMAPE. - Kyiv, 2015. - № 24 (3). - P. 206-213.

\title{
Microbiological monitoring of the development of children with congenital heart disease
}

\author{
Filonenko G. V. ${ }^{1}$, Salamanina A. A. ${ }^{1}$, Kyryk D. L. ${ }^{2}$ \\ ${ }^{1}$ Ukrainian Children's Cardiac Center (Kyiv) \\ 2 Shupyk National Medical Academy of Postgraduate Education (Kyiv)
}

The analysis of the problem of postoperative bacterial infection allow to highlight aspects, of discussions which presently are of particular relevance and importance for high-tech cardiac surgery. Objective: To determine the incidence of bacteremia and its etiological structure in infants with congenital heart disease (CHD). Methods. Microbiological, statistical analysis. Results. A comparative analysis of the results of bacteria logical stady of blood samples obtained from 218 infants were surgical treatment from 2015 to 2016y. It was ectablished that within the spectrum of pathogens of bacteremia in patients for $2015 y$ Non-fermenting gram-negative microorganisms (43.1\%), for 2016y - coagulase-negative staphycoccus (25.6\%) was predominant. Conclusions. Infants with CHD should be included into the risk group for bacteremia and other postoperative IC. Microbiological monitoring is one of the major components of infection control in cardiac surgery hospitals providing science-based antibiotic therapy and IC prevention methods. Further research should focus on determining the moleculargenetic determinants of antibiotic resistance, especially beta-lactamase and carbapenemase.

Key words: children, bacteremia, congenital heart disease.

\section{Микробиологический мониторинг развития бактериемии у детей с врожденными пороками сердца \\ Филоненко Г. В. ${ }^{1}$, Саламанина А. А. ${ }^{1}$, Кирик Д. Л. ${ }^{2}$ \\ 1 ГУ «Научно-практический медицинский центр детской кардиологии и кардиохирургии МОЗ Украины» (Киев) ${ }^{2}$ Национальная медицинская академия последипломного образования имени П. Л. Шупика (Киев)}

Результаты анализа состояния проблемы послеоперационной бактериальной инфекции позволяют выделить аспекты, обсуждение которых на современном этапе является особенно актуальным и значимым для кардиохирургии высоких технологий. Цель исследования - определить частоту развития бактериемии и ее этиологическую структуру у детей первого года жизни с врожденными пороками сердца (ВПС). Методы - микробиологические, статистической обработки. Результаты. Проведен сравнительный анализ результатов бактериологического исследования проб крови, полученных у 218 детей первого года жизни, прооперированных по поводу ВПС за период 2015-2016 гг. Установлено, что в спектре возбудителей бактериемии у детей в 2015 г. преобладали неферментирующие микроорганизмы (43,1\%), а у пациентов в 2016 г.- коагулазонегативные стафилококки (25,6\%). Выводы. Детей первого года жизни с ВПС необходимо включить в группу риска развития бактериемий и других послеоперационных инфекционных осложнений (ИУ). Микробиологический мониторинг является одной из основных составляющих системы инфекционного контроля в кардиохирургических стационарах, что обеспечивает научно обоснованную антибиотикотерапию и профилактику ИУ. Дальнейшие исследования должны быть направлены на определение молекулярно-генетических детерминант антибиотикорезистентности, в первую очередь к бета-лактамазам расширенного спектра действия и карбапенемаз.

Ключевые слова: дети, бактериемия, врожденные пороки сердиа. 